\title{
A música chega primeiro: a dupla mimese musical na Estética de Lukács
}

Fecha de recepción: 17/7/2020.

Fecha de aceptación: 24/10/2020.

\section{Resumo}

Este artigo, de caráter teórico-bibliográfico, debate sinteticamente o tópico " $\mathrm{La}$ música”, presente no capítulo 14 de Estética. A peculiaridade do estético, de Georg Lukács. Com base em leitura imanente, a comunicação, apoiada no autor húngaro, parte da característica fundamental do meio homogêneo musical, ou seja, de que a música partilha da condição de possuir uma dupla mimese. 0 caso musical, não obstante, considera a lei básica da refiguração estética lukacsiana para as demais artes, isto é: a largura, a profundidade, a amplitude, entre outros elementos da expressão da vida, são elementos de onde a arte retira o material vital para refigurar suas obras. Em outras palavras, o material fornecido pelo mundo, na mesma medida para qualquer arte, será o solo alimentador do material vital da conformação musical. A exposição aponta, como consideração do debate apreendido, que a música - assim como as outras formas de reflexão artística - e a vida partilham de um campo comum de contato, sendo esta a fornecedora do material vivencial para que aquela possa se alçar ao patamar de provocar catarse nos viventes.

Palavras-chave: Estética; Georg Lukács; Música; Meio homogêneo.

Music arrives first: the musical mimesis duo in the Aesthetics of Lukács

\author{
Abstract \\ This article, of theoretical and bibliographic character, synthetically debates the \\ topic "Musics", present in chapter 14 of Aesthetics. The peculiarity of the aesthetic,
}


by Georg Lukács. Based on immanent reading, communication, supported by the Hungarian author, is part of the fundamental characteristic of the homogeneous musical environment, that is, that music shares the condition of having a double mimesis. The musical case, however, considers the basic law of the Lukácsian aesthetic re-figuration for the other arts; that is: width, depth, breadth, among other elements of the expression of life, are elements from which art draws vital material to reshape his works. In other words, the material provided by the world, to the same extent for any art, will be the soil that feeds the vital material of the musical conformation. The exhibition points out, as a consideration of the apprehended debate, that music - as well as other forms of artistic reflection - and life share a common field of contact, this being the supplier of the living material, so that it can rise to the level of provoke catharsis in the living persons.

Keywords: Aesthetics; Georg Lukács; Music; Homogeneous medium

"Vou lembrando a revolução,

Mas há fronteiras nos jardins da razão."

Chico Science

\section{A duplicação mimética na música: uma introdução}

Para o autor húngaro, a música, a arquitetura, o artesanato artístico, a jardinagem e o cinema, guardando suas distintas especificidades, partilham da condição de possuírem em seus meios homogêneos a característica de uma dupla mimese.

O caso musical considera a lei básica da refiguração estética lukacsiana para todas as artes, ou seja, a largura, a profundidade, a amplitude, entre outros elementos da expressão da vida. Tais fatores fornecem o chão de onde a arte retira o material vital para refigurar suas obras. 0 material fornecido pelo mundo será o solo fornecedor do material vital de toda conformação musical.

Rever tais pressupostos torna-se preciso devido à seguinte problemática: ao tempo que a música se revela como uma grande arte, apresenta dificuldades para o devido entendimento de como se integra ao mundo humano. Portanto, não se pode avançar sobre o problema da música sem ter em mente que a arte e a vida partilham um campo comum de contato, sendo esta a fornecedora do material vivencial para que aquela possa se alçar ao patamar de provocar catarse nos viventes.

A peculiaridade específica da mimese musical, além de se realizar através de uma duplicação mimética, caracteriza-se por ser produzida diretamente da vida interior da pessoa humana. ${ }^{1}$ Esse reflexo da interioridade humana distingue, qualitativamente, a música das demais artes: "a mimese da interioridade como tal, não de uma interioridade conformada simultaneamente com sua ocasião 
desencadeadora, nem menos limitada à conformação do mundo externo para evocar assim o interior" (Lukács, 1967: 4/10). A música, é preciso insistir, nasce de uma necessidade social geral que, para ser satisfeita, cria seu peculiar meio homogêneo em forma de uma dupla mimese, dado que, como já pensavam os gregos, o objeto mimético da música é o interior do humano.

O problema metodológico para tratar adequadamente a tematização musical mostra-se, de maneira geral, do seguinte modo: se, por um lado, se tenta derivar a música considerando que a natureza biológica não se diferencia da natureza do ouvido humano, de outro, analisa-se a problemática derivando-a também em relação direta da filosofia natural. Os dois pontos acabam por representar um princípio básico comum: vinculam a música diretamente a fenômenos da natureza, procurando deduzir o elemento musical diretamente do natural.

No primeiro caso, temos o exemplo de Johann Herder. Ele se aproxima do problema pela superfície sensível imediata, desconsiderando completamente o papel do trabalho na evolução e refinamento dos sentidos humanos. A segunda concepção, por sua vez, acredita que a mimese musical é um produto secundário e, em parte, alheio e distante da intenção concreta do criador.

O caminho metodológico que deve ser aplicado ao elemento musical precisa enfrentar a tematização da objetividade indeterminada. A indeterminação da objetividade é uma questão própria ao campo estético. No caso da música, pelo fato de aqui não se tomar o mundo externo como referência, a problemática da objetividade é radicalmente aprofundada. Isto é, o meio homogêneo musical, sua linguagem específica, produz uma objetividade radicalmente indeterminada.

Existem muitos obstáculos quando se tenta encaixar a arte num conceito metafisicamente rígido. Essas dificuldades relacionam-se diretamente com a capacidade que a arte possui de produzir certa objetividade indeterminada. Como o reflexo artístico, em sua movimentação estética tem como solo a imanência concreta do mundo pedestre, rejeitando ao mesmo tempo qualquer caráter de verificabilidade com a realidade concretamente dada, sua definição em um conceito rigidamente fechado é muito difícil. Apenas a obra em sua autenticidade acabada consegue expressar e, por conseguinte, evocar alegrias, tristezas, esperanças, dores etc. nos receptores. Isso ocorre porque o ser-em-si da obra fechada não é a realidade concreta, senão a refiguração do real: representa, com base na realidade, o inefável e, com efeito, o que o mundo pode vir a ser (Santos, 2018).

Para o caso do reflexo mimético duplicado pela música, a objetividade indeterminada ganha destaque privilegiado. Por esses motivos, teremos de nos ocupar um pouco mais com a objetividade radicalmente indeterminada do reflexo musical.

Como adiantamos (Santos, 2020), toda determinação, para garantir a precisão e a univocidade do que se procura determinar contém, dialeticamente, elementos de indeterminação. Determinação e indeterminação são, portanto, funções da totalidade intensiva do mundo circundante. 
Para o devido tratamento dessa questão é preciso considerar, com nosso autor, que determinação e indeterminação são funções da totalidade intensiva concreta do trabalho. Isso implica dizer que a determinação, para que possa proteger a precisão e a univocidade do que se procura determinar, necessita conter, dialeticamente, elementos de indeterminação.

A classe das determinações estéticas não foge a essa incorporação dialética. 0 caso artístico mostra alguns princípios que podem ser formuláveis com precisão, não obstante, desconhece qualquer regra geral universalmente aplicável que lhe confira caráter formalista. Quando o escritor, para citar o exemplo da literatura, tenta uma descrição precisa de suas personagens, inclina-se para a hiperdeterminação e não para a determinação artística. Se o hiperdeterminado ganhar a preponderância nas personagens, o que ocorre na maioria dos casos de descrições hiperdeterminadas, o resultado tende ao supérfluo.

O que importa destacar, para as legítimas tentativas de refiguração da realidade, é o campo de jogo, tensão e ludicidade das determinações indeterminadas. Esse campo de ação já está presente na realidade cotidiana. A obra acabada busca sua objetividade no conteúdo real, uma vez que é a realidade que guarda os elementos intelecto-emocionais que devem ganhar conformação no corpo da obra fechada. A busca do que é essencial no drama humano nunca é um dado fixo; movimenta-se entre muitos pontos. Por isso, o drama pessoal da humanidade não pode ser rigidamente determinado. Carregará, sempre e ineliminavelmente, seu caráter indeterminado.

A articulação dialética da determinação do que é externo ao sujeito humano com o humano-psíquico que ele internaliza monta o âmbito do movimento da tensão lúdica que caracteriza a essência do que deve ser buscado pelo efeito estético. A objetividade artística, por ser nascente na essência do drama humano, não é completamente indeterminada, tampouco rigidamente determinada. Há, no âmago do drama humano, um movimento entre a determinação e a indeterminação. No campo de movimentação entre o que se pode determinar e o que é de difícil determinação move-se a esfera estética. 0 movimento especificamente artístico opera, com efeito, nesse campo de jogo.

A objetividade indeterminada tipicamente artística, uma vez que se movimenta nesse campo de tensa ludicidade, cobra conteúdos concretos que, por força da ação estética, são determinados de maneira qualitativamente diferente de como a objetividade se apresenta na vida cotidiana. Os elementos colhidos desse campo de jogo estético, ao serem apresentados pela pura visualidade do sujeito receptor, chegam-lhe, pela ação do meio homogêneo da arte de que se trate, como um mundo objetivo e precisamente determinado.

É oportuno destacar que mesmo sendo um mundo estruturalmente de conteúdo humano, a conformação visual que chega ao receptor possibilita a movimentação do debatido espaço de tensão e jogo entre o que se determina e a indeterminação presente objetivamente. Ou seja, o objeto que tem seu conteúdo determinado por 
meio de uma dada forma logra êxito em conexão com certa indeterminação desse mesmo conteúdo. Isso requer o registro de que tal movimentação, no campo estético, é distinta para cada obra e para cada estilo artístico dado. Importa ainda advertir, sempre com Lukács, que vai depender de cada arte específica e de cada estilo de que se trate a qualidade daquilo que deve permanecer necessariamente indeterminado e o que precisa ganhar mais determinação formal.

Os conteúdos que se mantêm indeterminados, quando se trata da esfera artística, contudo, não ficam completamente sem nenhuma determinação. Isso se justifica, dado que o sujeito humano, imerso em sua dinâmica cotidiana, não consegue penetrar o conteúdo particular da vida em sua totalidade; como se sabe, o faz apenas parcialmente: sempre lhe escapa algo. A indeterminação artística, antes de se constituir como tal, ganha, portanto, uma clara determinação.

Resta responder à seguinte indagação: a possibilidade de que nasça no interior humano um conteúdo que possua uma determinação indeterminada depende de quais elementos?

Como debatemos em Santos (2018), com base na Grande Estética de Lukács, chegamos à seguinte síntese: para que a obra reproduza a dialética que gera certo conteúdo que, por sua vez, é determinado por uma indeterminação, é preciso que a conformação tenha força suficiente para se determinar visualmente ao sujeito humano (para atrair a sua atenção). Se, por um lado, essa exterioridade visual ganhar tamanha determinação ao ponto de anular a indeterminação, a refiguração se inclina para as descrições hiperdeterminadas e, por isso, o máximo que pode lograr é algum êxito naturalista. Se, ao contrário, se constituir como uma completa indeterminação que assume o domínio perante o alcance visual do receptor, há o aniquilamento da esfera da interioridade; em consequência desse aniquilamento, esvazia-se o conteúdo externo. Se esse segundo caso for exitoso, produz-se a arbitrariedade subjetivista, pois a capacidade orientadora do conteúdo se perde, dando luz à incapacidade artística, o que faz surgir, no limite, o diletantismo estético.

Mesmo com todos esses elementos aclarados, não se pode traçar uma fronteira que separe rigorosamente as obras produtoras da determinação indeterminada e as criações que não alcançam tal caráter. Existem muitas conexões entre os dois extremos. Aqui repousa mais uma das muitas dificuldades de se precisar a arte num conceito fechado rigidamente. ${ }^{2}$

2 Citamos como ilustração e esse processo, em Santos $(2018,285)$, o seguinte: "Quando a representação figurativa do mundo circundante que não é humano aparece humanizada na arte, essa reprodução vem de um considerável esforço artístico por reproduzi-la antropomorfizadoramente ao sujeito humano em relação ao seu mundo objetivo. No caso das artes figurativas, tal esforço procura orientar-se de tal modo que essas relações apareçam puramente como propriedades visuais dos objetos representados, como suas relações recíprocas visuais. Na vida concreta, o que aparece isolado e encoberto pelas finalidades imediatas do dia a dia, nas artes figurativas, a partir de um esforço conformativo, ao converter-se artisticamente, levanta-se à universalidade guiado pela representação de um mundo apropriado ao humano e, por isso, perfeito e fechado em si, em seus elementos estéticos. É assim que a objetividade indeterminada exige seu ambiente de brincadeira, jogo e tensão, cujos conteúdos concretos, em virtude do ambiente criado por essa ludicidade, são determinados de um modo qualitativamente diverso de como ocorre na vida cotidiana". O próprio Lukács (1966: 2/420) utiliza uma fala de Rilke sobre as maçãs de Cézanne; diz o esteta húngaro: "a determinação simples pelo conteúdo 
Em problemas como esses, apenas o apelo à dialética ontomaterialista pode criar condições de avanço. Lukács, para enfrentar essa problemática, recorre à Lógica de Hegel. Sob as orientações do filósofo alemão, o marxista magiar entende que a categoria da medida é a simples relação do quantum consigo mesmo. A concreta relação do ser, sua determinação em si mesma, portanto, é um quantum qualitativo. Em uma expressão: a fusão dialética da quantidade na qualidade.

Com esse requinte metodológico como luz e com as considerações sobre o desenvolvimento do ritmo em dependência ontológica e reciprocidade dialética em relação à divisão social do trabalho, o esteta húngaro considera-se em condições de melhor expor o problema, aplicando-o, por sua vez, ao campo musical.

Para isso, torna-se necessário abordar a questão da interioridade humana, uma vez que, como visto, a música duplica sua mimese exatamente por ser sentida pelo sujeito humano primeiramente em sua mais íntima interioridade. Depois de adiantada, mesmo que de modo preliminar, a objetividade indeterminada, precisamos, agora, tematizar a interioridade humana em relação à objetividade radicalmente indeterminada produzida pelo campo musical.

O autor, sobre a base metodológica recém-anunciada, descreve que, do mesmo modo como o aumento da produtividade do trabalho desenvolve intelectualmente o trabalhador, consequentemente, provoca um maior domínio do sujeito sobre o mundo externo. Cumpre reforçar que esse processo de maior liberação das capacidades somáticas humanas dá-se, sobretudo, pelo fato de que o ócio demanda uma menor absorção do sujeito humano pelo processo de trabalho. 0 desfrute do ócio, mesmo que em potência e apenas para uma classe, retroage diretamente no âmbito da interioridade da vida humana emocional.

A interioridade humana, desse modo, é influenciada pela seguinte relação: divisão social do trabalho e potência do ócio. Tal articulação é de aguda importância para o devido tratamento da problemática da duplicação mimética na música, pois não se pode duvidar de que há uma intricada vinculação entre a interioridade humana e as situações objetivas vindas do mundo externo que circunda os sujeitos viventes. Mesmo que os sentimentos interiores não contenham afirmações diretas acerca dos objetos que os fazem surgir, estão ligados de modo intenso ao conteúdo, à intensidade etc. dos objetos que os suscitam na exterioridade humana. Não há como sentir imediatamente determinado afeto, por exemplo, amor ou ódio, sem que eles estejam determinados por uma relação pessoal circunscrita a uma determinada situação.

Por muito que hoje seja comum se falar em afetos, como o temor ou a esperança, o amor ou o ódio etc., "[...] é seguro que [tais afetos] tenham existido muito tempo

da fruteira das maçãs concreta-se em um preciso valor de sensação e pensamento, no qual, no entanto, não se pode esquecer que essa consideração de Rilke não se refere, de todo modo, mais que a uma objetividade indeterminada". Isto é, não se pode comer as frutas refiguradas por Cézanne. Ver, por exemplo, o quadro "Cestas de Maçãs", Paul Cézanne (1895). 
em formas concretas sumamente diferenciadas, e desse modo tenham agido antes que os homens os reduzissem como afetos específicos a um comum denominador conceptual unificador" (Lukács, 1967: 4/17).

A esse momento da vida humana em que os seres sociais não conseguem definir um sentimento por meio de um conceito fixo em uma palavra, o filósofo húngaro denomina de início da interioridade humana. É aqui que o sujeito vivente começa a entender que possui uma interioridade.

Para explicar como isso ocorre, o nosso autor recorre ao modo de vivência do trabalhador primitivo. No estágio do modo de produção primitivo em que o vivente não conseguia, pelo incipiente desenvolvimento da linguagem articulada, organizar e assim passar à consciência os sentimentos de modo que eles pudessem ser sintetizados através de palavras - como alegria, tristeza etc. -, produz-se, por meio do ritmo, a potencialização da mimese relativa a tais afetos. Como se evidencia, Lukács relaciona o começo da liberação da interioridade humana com o trabalho e sua divisão social.

Em síntese: do estado em que o sujeito ainda não reduzia os sentimentos a um conceito fixo, processa-se uma mimese que, por sua natureza, tem como base tais sentimentos. Essa mimese encontra a potência para seu desenvolvimento, exatamente, no ritmo.

Não se pode deixar de destacar que o caráter artisticamente evocador dessa classe mimética se produz como produto secundário. No processo de desenvolvimento da interioridade humana, em sua fase original (in nuce), a mimese originária não tem caráter artístico, pois sua operacionalidade era dada pelas forças mágicas. Os elementos artísticos dessa mimese original são, parcialmente, alheios à intenção concreta, haja vista que a mimese em sua forma mágica cobra certa aura evocadora que, de todo modo, ainda não é artística.

Essa cobrança não permite que o reflexo evocador seja, por um lado, totalmente artístico, nem, por outro, completamente mágico. 0 caminho que desemboca, decisivamente, no estético é, em certa medida, casual. Os caracteres decisivos da música como mimese da interioridade humana - "[...] os afetos, as impressões etc., suscitados - desenvolvem-se, portanto, sob uma capa mágica, como meios técnicos auxiliares, por assim dizer, de uma finalidade mágica; e pouco a pouco, chegam à substancialidade do estético" (ibíd.: 4/18).

Até que o efeito musical alcance seu estágio propriamente mimético, antes, ele precisa primeiramente desenvolver-se a partir do ritmo próprio da natureza. $\mathrm{Ou}$ seja, desenvolver-se com base no ritmo biológico existente nos seres vivos que, por seu caráter, são fundados sob os reflexos incondicionados ou condicionados. Estágio imprescindível para o desenvolvimento humano, uma vez que o ritmo, ainda em sua adaptação do biológico ao social, facilita a adaptação humana ao ambiente circundante. 
Nesse estágio, seguindo orientação da divisão social do trabalho, há um salto qualitativo que leva o ser social ao estágio seguinte: a organização espaço-temporal que segue uma finalidade prática imediata. Isso resulta em uma maior facilitação do trabalho e em uma consequente maior produtividade, o que garante, por seu turno, certa dose de satisfação ao sujeito trabalhador.

Mesmo que a satisfação aqui seja um elemento secundário, que o efeito agradável ainda não seja completamente consciente, importa ressaltar que é desse ponto que surgem os cantos de acompanhamento já com expressões verbais articuladas. A transição entre o momento do ritmo como facilitador do trabalho para o trabalho ritmado por cânticos vocálicos é muito importante para o aparecimento da melodia e da harmonia, por exemplo.

Se se compara esse processo com o da dança, pode-se indicar que no caso da segunda, em todas as sociedades primitivas, desde o seu princípio, a dança é de caráter mimético-evocador, enquanto a música transforma sua essencial natureza humano-evocadora em elemento estético.

Pois ainda que [...] haja entre diversas espécies de arte da palavra e a música uma conexão mais profunda que entre esta e a dança, a evolução histórico-social acarreta, ao mesmo tempo, no primeiro caso, uma distinção mais precisa; até a lírica se desprende progressivamente do acompanhamento musical obrigatório, e a música logo se torna capaz de expressar sem palavras sentimentos líricos. (ibíd.: 4/21).

Vale advertir, contudo, que a dança não pode se separar nunca da música. Mesmo quando aquela deixa de ser encarnação mimética de importantes fatos da vida, como ainda ocorre em determinadas cerimônias tradicionais, sobretudo as que se realizam no campo e distante dos grandes centros urbanos, acaba por se converter, na vida cotidiana, em mera diversão. Inclusive nesses casos, a dança jamais deixa de ter sua fundamentação organizadora na música. ${ }^{3}$

Essa junção é o que justifica ater-se um pouco mais na articulação entre música e dança, sobretudo porque a mimese que se realizava nas danças nos tempos primitivos tinha relação direta com a preservação e com a conservação dos fatos mais importantes da vida cotidiana. Pense no exemplo das danças guerreiras. A música, no entanto, mesmo em momentos de nascimento, não podia limitar sua função organizadora a ritmar movimentos recorrentes, porquanto se afastava, logo no início de seu desprendimento, de uma função imediatamente prático-factual.

Essa oscilação entre o necessariamente imediato e a interioridade humana iluminou a relação entre música e dança no mundo primitivo. Aqui, cabe mencionar que a gesticulação humana carrega toda uma gama de elementos refletidos a partir da interioridade do ser social que gesticula, mesmo que não haja, conscientemente, uma precisa articulação entre o gesto e o que interiormente desencadeia a gesticulação. 
O que mais importa para o debate que agora se trava é destacar que é a música que ordena os movimentos gestuais da dança. A mimese desta organiza a fundamentação daquela. A essência desta ordenação é predominantemente temporal, o que é uma propriedade da natureza da música. Não se pode desconsiderar que a ordenação expressiva dos gestos dos sujeitos dançantes seja obra de uma coreografia, pois, com efeito, tal organização coreográfica estará sempre submetida à ordenação musical.

É necessário pontuar que a música, eminentemente temporal, serve de base organizativa para a dança, que tem predomínio tempo-espacial. Esse debate tornase importante por vincular-se ao problema acerca da separação entre tempo e espaço, que, por sua polêmica, ganha foro privilegiado na contemporaneidade.

Os preconceitos sobre a articulação dialética entre o tempo e o espaço adquirem visibilidade em Kant (2001), uma vez que o filósofo de Königsberg, na Crítica da razão pura, postulou com rigidez metafísica a separação entre o tempo e o espaço, atribuindo para este uma relação com o mundo externo e para aquele uma referência com a interioridade humana.

O tempo, escreve Kant (2001: 98, §A33), “não é algo que exista em si ou que seja inerente às coisas como uma determinação objetiva e que, por conseguinte, subsista, quando se abstrai de todas as condições subjetivas da intuição das coisas". O grande filósofo idealista, mais à frente, considera que "o tempo não é mais do que a forma do sentido interno, isto é, da intuição de nós mesmos e do nosso estado interior" (p. 99, §B50). Para ele, "o tempo não pode ser uma determinação de fenômenos externos; não pertence a uma figura ou a uma posição, antes determina a relação das representações no nosso estado interno" (ibíd.: 99, § B50).

E ainda:

[...] precisamente porque esta intuição interna se não apresenta como figura, procuramos suprir essa falta por analogias e representamos a sequência do tempo por uma linha contínua, que se prolonga até ao infinito e cujas diversas partes constituem uma série que tem apenas uma dimensão, e concluímos dessa linha para todas as propriedades do tempo, com exceção de uma só, a saber, que as partes da primeira são simultâneas e as do segundo, sucessivas. Por aqui se vê também que a representação do próprio tempo é uma intuição, porque todas as suas relações se podem expressar numa intuição (ibíd.: 99, § B50).

Segundo Lukács, Hegel definiu de modo indestrutível a teoria da cofiliação entre o espaço e o tempo. Para o esteta de Budapeste, esse é o único caminho para se compreender adequadamente a matéria em seu movimento e, assim, possibilitar a compreensão da peculiaridade da música: sua mimese dupla (mimese da mimese).

Sustenta Lukács (1967: 4/31) que “[...] passado, presente e futuro constituem, por uma parte, cada um, uma unidade dessa contraposição, e, por outra parte, distinguem-se um do outro em relação a nascer e perecer". Para o autor, apenas 
na geometria, por conseguinte no ornamento geométrico, pode-se praticar com validade uma abstração em que a posição de um espaço exista sem tempo. 0 marxista húngaro conclui que nem mesmo a forma mais abstrata do tempo pode prescindir do espaço; a matéria precisa estar em dialética com o movimento.

Como todo decurso temporal concreto carrega um caráter histórico, tal como indicou Heráclito de Éfeso em sua famosa formulação entre o banhar-se humano e a passagem das águas de um rio, a continuidade do tempo deve ser concebida, em princípio, em seu aspecto objetivo. Numa expressão: a alteração qualitativa obtida com o decurso temporal dá-se no mundo objetivo. Aqui não há necessidade de sujeito para conferir a tal temporalidade um caráter histórico. 0 complicador está no fato de que determinados acontecimentos ficam longos lapsos de tempo sem ser percebidos como importantes para a história da humanidade; e quando entendidos como decisivos, nem sempre são registrados imediatamente como fruto da síntese da ação subjetiva do humano sobre a matéria histórica.

Esse desdobramento de fundo carrega a verdadeira natureza do reflexo dos processos temporais para o fazer artístico, visto que exprime a essência do decurso temporal na arte. Isto é, o universal nascer e morrer de cada objetividade concreta, por meio do reflexo do decurso temporal, conecta-se ao ser real de cada subjetividade em cada momento dado.

Com base, portanto, na cofiliação entre espaço e tempo, já se pode expor a problemática da dupla mimese musical, haja vista que a articulação do espaço e do tempo, determinada na vida cotidiana, exige, por intermédio do trabalho, uma posterior elaboração, conseguida por meio do ritmo. A música, se ordenada sob a orientação do ritmo, assume sua temporalidade sem perder de vista os elementos espaciais, denominados por Lukács (1966:2) de quase-espaço. ${ }^{4}$

Nessa intensificação qualitativa, o mundo das impressões psíquicas humanas, para garantir seu pleno desenvolvimento, separa-se do mundo externo objetivo que, por força de sua objetividade, desencadeia tais impressões (primeira mimese). A dialética do predomínio do decurso temporal com o espaço, presente na música, faz com que a internalização subjetiva se referencie retroativamente na estrutura objetiva do mundo externo (segunda mimese); isso exige a patente de uma interioridade autenticamente humana. Tal processo, ao transformar as relações humanas num cosmos de interioridade, filtra para o interior humano o que lhe dá o selo de autenticidade, deixando de fora o veneno narcisista de uma existência vã que, por sua debilidade, poderia conquistar o mundo para si apenas na aparência formal.

4 Como já analisado em Santos (2018), o esteta divide as artes em dois grandes grupos: o primeiro, em que o meio homogêneo é predominantemente temporal, e o segundo, em que predomina o meio homogêneo espacial. Naquele, os exemplos utilizados pelo esteta são a música e a literatura; neste, ele usa como ilustração o caso das artes plásticas. Não se pode esquecer, evidentemente, que tal separação não existe de modo rígido como querem as precipitadas avaliações metafísicas. Repetindo: não há divisão entre o tempo e o espaço no caso da estética, o que de fato ocorre é o predomínio, em determinadas artes do quase-tempo e, em outras, do quase-espaço. 
A música chega primeiro: a dupla mimese...

Para que fique ainda mais claro como se opera na música a mimese da mimese, atentemos às palavras de Lukács (1967: 4/33):

Ao transformar o presente, o passado e o futuro conformados na música - sem destruir sua essência originária - em uma cofiliação vivenciada, converte-se efetivamente em uma plenitude temporal, em sua própria superação subjetiva. Porém, como este ato não é mais que um reflexo, uma realização subjetiva do que encontra em si na essência do tempo concreto e objetivo - a saber, uma cofilição inseparável, entitativa, com o espaço e com a matéria que se move neste -, tal ato perde todo rastro de arbitrariedade subjetivista.

Para que a relação empírica entre dança e música fique definitivamente clara, usamos como contraexemplo o caso da poesia. A utilização do meio homogêneo da poesia se justifica uma vez que ela, como a música, desenvolve seu meio homogêneo no decurso temporal, no entanto, não carece de operar uma dupla mimese.

A temporalidade na poesia é refletida em seu modo concreto e em sua historicidade, criando a dialética do nascer e morrer, da continuidade e descontinuidade. Essa dialética, porém, cobra uma forma tal que a realidade objetiva deve ser refletida na subjetividade da interioridade humana. Portanto, por meio de uma mimese direta: do mundo externo para o interno. Ou seja, na poesia não há duplicação mimética, embora seja patente a presença do despertar da interioridade humana.

Para que fique mais claro como funciona a mimese em relação à interioridade humana, temos de tocar, mesmo sem a devida profundidade, no nódulo da questão: a relação geral entre a vida interior humana e os desdobramentos de seu destino externo. Tal relação possibilita uma melhor compreensão das especificidades dos sentimentos e das impressões que os sujeitos têm na vida.

O ponto de partida dessa temática é a consideração, por um lado, de que os sentimentos e as impressões, bem como os demais elementos da interioridade humana, nascem exclusivamente da interação entre o sujeito humano e o mundo que o circunda; por outro lado, a esfera da individualidade é muito mais ampla do que o campo dos sentimentos e das impressões. Ademais, não se pode ignorar que os sentimentos e as impressões constituem uma classe de reflexo da realidade com muito mais força subjetiva, distanciando-se, por sua natureza, das tendências que se aproximam desantropomorfizadamente do real. ${ }^{5}$

Estando claro que sentimentos e impressões possuem grande força subjetiva, é preciso que se afirme o seguinte: assim como o reflexo desantropomórfico precisa guardar distância da vida cotidiana, de modo que possa realimentá-la, o reflexo

5 No Velho Testamento, especificamente em Jeremias (9: 17,18), lê-se: "17. Assim diz o Senhor dos Exércitos: Considerai e chamai carpideiras, para que venham; e mandai procurar mulheres sábias, para que venham também" (p. 1.369). Em algumas traduções, encontra-se a expressão carpideiras traduzida como pranteadoras. No sertão brasileiro, sobretudo no nordestino, ainda hoje é comum - embora menos que antes - a contratação de profissionais que recebem dinheiro para cantar músicas tristes nos velórios e com isso causar comoção nos presentes. Os contratantes objetivam garantir que haja tristeza no funeral. Para eles, nada mais triste do que uma inumação sem tristeza. 
artístico também necessita afastar-se da cotidianidade para poder retroagir sobre a vida prática imediata. Mediante a suspensão do vínculo com os conteúdos e as formas presentes na cotidianidade, o mundo humano se converte em conformação, de modo que o sujeito humano, por meio da obra de arte, tem agora como tomar posição sobre sua vida.

Há de se considerar, por fim, que tanto a vida externa como a interna - a interioridade humana - precisam submeter-se à dinâmica do que ocorre na realidade concreta. Se, por um lado, o vivente tem os elementos concretos da realidade dada, por outro, tem seus sentimentos e impressões carregados de forte dose subjetiva. Sentimentos e impressões, não obstante, agem de maneira completamente distinta do que ocorre em relação ao mundo externo, visto que eles não se submetem a uma prática de orientação teleológica.

\section{A mimese das emoções: uma objetividade radicalmente indeterminada}

Com a antecipação de como se comportam os sentimentos e as impressões em relação à orientação teleológica, já se pode retomar uma questão central para o aclaramento da dupla mimese presente na música. Esse reflexo artístico, quando relacionado ao mundo externo, guarda a aparente antinomia da existência de uma objetividade radicalmente indeterminada. ${ }^{6}$ Tematizar a questão deixará a exposição em melhores condições de se aproximar, rigorosamente, da especificidade da música que, por seu caráter, opera sob a ação de uma dupla mimese.

Como já esclareceu Marx (2008), todo paradoxo, quando tem suas particularidades iluminadas, explica-se por si só. Isso ocorre com o caso musical do seguinte modo: por um lado, há um distanciamento vital e, por outro, uma proximidade de igual vitalidade. Para Lukács, se se considera o postulado spinoziano da negação como determinação, pode-se ver que a distância em relação à vida, operada no caso da música, funde-se por si mesma com a suprema proximidade à realidade, dado que anuncia a essência mais subjetiva e interna do humano.

Explicando com mais detalhes. Por uma parte, o meio homogêneo musical não tem relação direta com o mundo externo, com a realidade objetiva desantropomorfizada, o que o impede de produzir imediatamente uma mimese nesse

6 Toda determinação, para que possa proteger sua precisão e univocidade, precisa conter, dialeticamente, elementos de indeterminação. A classe das determinações estéticas não foge a essa incorporação dialética. Determinação e indeterminação são, portanto, funções da totalidade intensiva. O caso artístico, indubitavelmente, mostra princípios formuláveis com precisão, embora desconheça qualquer regra geral universalmente aplicável que lhe confira caráter formalista e metafisicamente fechado. Quando o criador tenta uma descrição precisa de seus personagens, ocorre não uma determinação, senão uma hiperdeterminação que, na maioria das vezes, inclina-se ao supérfluo. A determinação indeterminada que se aplica ao caso estético é, para Lukács, uma dada determinação que carrega em si graus de indeterminação. Para citar um exemplo utilizado pelo autor, uma morte na refiguração artística não é uma morte real, assim como numa cadeira pintada em uma tela não se pode sentar. Isso remete ao que Lukács (1967: 4/9) recorda da importante ideia aristotélica segundo a qual o que na vida é feio ou desagradável pode produzir alegria mimeticamente. Esse pensamento, segundo o autor da Grande Estética, já se encontra em Píndaro. 
sentido; por outra, esse mesmo meio homogêneo, exatamente por estar impedido da missão de refigurar o externo, resta liberado para expressar, sem inibições e com depuração, os sentimentos e as emoções humanas com toda a plenitude.

Para que o paradoxo se desfaça completamente, vale anotar que como as emoções e impressões do agir humano não se desprendem da realidade objetiva, do mundo externo, a música opera essa radical depuração: “[...] mediante a posição de uma nova mimese que duplica aquela outra espontânea" (ibíd.: 4 44),

\section{Mas como isso acontece?}

Lukács (ibíd.: 4/44) explica que na dupla mimese, ou seja, no meio homogêneo produzido pelos sons, "[...] os sentimentos e as emoções refiguradas, mediante a objetividade [radicalmente] indeterminada, perdem toda vinculação a coisas externas e podem desdobrar-se plenamente de acordo com sua própria lógica e sua própria dinâmica".

Não se pode esquecer, contudo, que esse processo ocorre ao tempo que o refletido se mantém como verdade do modelo vital. Motivado por tal manutenção, a formação mimética garante totalmente a preservação e, inclusive, cobra possibilidades de que se cumpram elementos que, na vida concreta, necessariamente seriam inacessíveis. Aqui também há um aparente paradoxo, pois elementos que na vida concreta eram elos mais frágeis de um comportamento, por meio da mimese objetiva e radicalmente indeterminada, convertem-se no fundamento de uma máxima capacidade evocadora do material vital elaborado mimeticamente.

Para evitar equívocos, repetimos que a operação da dupla mimese no caso musical respeita todas as leis aplicadas ao campo estético: na música, revela-se uma relação única em que o sujeito humano encontra a realidade com base na sua mais profunda interioridade. Esse fato diferencia a música vivencialmente das demais artes; no entanto, distingue-a com concretude estética.

A música se constitui como arte independente quando a mimese dupla, ou seja, quando a mimese das emoções desencadeadas pela vida ou quando a refiguração de uma refiguração possui a capacidade de conformar um objeto próprio, com suas propriedades e estruturas específicas. Numa expressão: desprendida da vinculação direta da situação vivenciada. Esse é o cenário da evolução históricosocial que permitiu à interioridade da vida emocional crescer até se converter numa potência vital de consideração social substantiva, o que possibilitou à mimese musical das emoções objetivar-se como forma para-si.

A diferenciação entre a música e as demais artes fica clara quando se contempla o meio homogêneo. 0 meio homogêneo das outras artes reflete imediatamente a concreta objetividade externa e interna da humanidade; as diferentes formas assim alcançadas criam sua homogeneidade de modo que possa suscitar evocações a partir de tais formações. 
O meio homogêneo musical, de modo distinto, limita-se exclusivamente ao papel de orientar a evocação. Ele não descobre, tampouco realiza, as possibilidades orientadoras e evocativas presentes nas concretas formas objetivas da vida. Sua missão é purificar e elevar até a forma artística o material psíquico que, por sua própria natureza, já carrega certo caráter evocador existente já na interioridade humana. Isto é, por meio da música, soergue-se o que está latente no interior do sujeito humano à condição vivencial de quem sente.

Resta, para avançar, responder qual a missão da interioridade na vida humana. A interioridade humana não pode se preocupar com a possibilidade de realização prática, tampouco deve se ocupar com o destino histórico das exigências confusamente contidas nos sentimentos, “[...] senão desdobrar, puramente e sem inibições, essa sensibilidade cósmica, na medida em que aqueles sentimentos podem ser na vida exigências do dia e da época, até fazer deles um 'mundo' maduro e completo" (ibíd.: 4 57).

A música tem a veracidade mais profunda e mais rica, uma vez que expressa os sentimentos com uma consumada perfeição interna e com uma pureza sem reservas. Esse processar refigurativo da interioridade humana pela música chega a ser pensado como irreal, porquanto adquire plena independência do imediato da situação momentânea das lutas sociais, pois “[...] o mundo dos objetos e as relações reais, em cujo marco se desenvolvem aquelas lutas, desaparece na música ou fica visível, no máximo, no horizonte, como alusão distante" (ibíd.: 57).

A característica particular da música está no fato de que, em seu meio homogêneo, a transformação do homem-inteiro em homem-inteiramente é mais enfática do que nas demais artes. Isso se dá porque o Antes, nascido da vida concreta, não consegue inibir a transformação tanto quanto nas outras artes. Pela natureza da refiguração musical, o Depois do efeito artístico fica bem menos determinado pelo conteúdo, ou seja, menos orientado a conteúdos determinados. Todo esse processo ocorre em virtude da radical objetividade indeterminada, que é o elemento de princípio da música, e por uma consequência necessária, para satisfazer sua essência estética como refiguração da totalidade emotiva. Processa-se assim por meio da mimese de uma mimese.

Essas propriedades imanentes ao elemento estético musical produzem uma rica e ilimitada gama de gradações que esclarecem a relação do campo musical com o mundo objetivo duplamente refigurado. Aqui há de se tomar o cuidado para não esquecer que a escala é extensa e com muitas variações intermediárias. Deve-se considerar que a gradação se posiciona entre a plena indeterminação - a partir de fora, vinda do mundo externo - e as determinações marcadas pela interioridade humana.

Essa cofiliação entre o determinado e o indeterminado objetivamente possibilita desfazer as aparentes antinomias presentes no campo musical, uma vez que a música cria o aparente paradoxo da estar, ao mesmo tempo, muito próxima e muito distante da vida, pois contém, de modo mais imediato, as categorias das 
decisões éticas, no entanto, de modo que intervém menos concretamente nelas. A música, por tais características, consegue comover os ouvintes de modo mais imediato e avassalador do que as demais artes, porém, ao mesmo tempo, é menos influenciada pelo efeito construtivo do Depois da comoção catártica.

Não se pode cair na separação mecânica entre a objetividade indeterminada - referente ao mundo externo - e a determinada - vinculada à interioridade humana. É preciso ter em mente que a objetividade indeterminada está sempre e em toda parte vinculada à determinada. Esse vínculo, do ponto de vista esteticamente concreto, apenas escassamente pode ser separado, visto que somente por meio da determinação interna pode a indeterminação objetiva chegar a se manifestar.

Assim: "Não há dúvida de que tudo o que na objetividade indeterminada se concreta mais ou menos como conteúdo, intensidade, orientação etc. dos sentimentos musicalmente refigurados, desempenha um papel decisivo na excussão da composição musical" (ibíd.: 4/71). Há de se atentar para o fato de que a cofiliação tem como consequência que "[...] as alusões autênticas, resolvidas ou vacilantes, ao conteúdo emocional último de uma obra 'pode' facilitar também sua compreensão puramente estética" (ibíd.: 71). 0 autor acentua a palavra "pode", pois nunca é demais repetir que "[...] todo exagero mecânico de tais alusões ou comentários pode também produzir uma ignorância do conteúdo propriamente dito, do autêntico mundo das formas" (ibíd.: 72).

Do ponto de vista puramente artístico, Lukács acredita que as tendências gerais de toda evolução indicam que a linha principal, da independência da música das demais artes, está na vinculação entre a dança, o canto e a música. Esta articulação se desdobra e desenvolve-se com saltos e recuos, lenta e às vezes rapidamente, de modo que esse desenvolvimento atinge certa diferenciação que desemboca na independência. Cabe lembrar, com Marx (2008), que a humanidade apenas se põe tarefas que pode realizar. Isso quer dizer que a música como refiguração substantiva da vida apenas pode existir quando as condições materiais da sociedade viabilizam as condições artísticas.

O mais importante para a nossa temática é entender que há uma ineliminável atração da palavra, do gesto e da dança, que são, por sua vez, consumados na música. Quando aquelas artes entram no campo musical, cria-se uma mediação que reorienta o meio homogêneo da música na direção de uma determinação, mesmo que relativa. Essa determinação, entretanto, seria impossível esteticamente se não houvesse tal mediação.

A articulação, por exemplo, da manifestação psíquica concreta da palavra ou da expressividade dos gestos da dança com a música nada mais é do que a confirmação de que o campo musical põe em movimento a sua articulada cofiliação. Por mais que se modifique o papel social da música com a entrada dessas outras manifestações artísticas, tal articulação apenas se movimenta sobre a base de uma concreta situação social. 
Essa situação, ao tempo que é concretamente social, contudo, amarra-se profundamente à essência da mimese musical, haja vista que sua forma específica de uma objetividade radicalmente indeterminada abarca o que se expressa na palavra e no gesto. Estes, por suas forças refigurativas, desencadeiam emoções miméticas no meio musical. Tal situação é bem evidente no caso específico da dança. Como já abordado, na dança há a produção de uma consumada unidade de emoção e manifestação, que em tempos primitivos era muito mais íntima e intensa do que em estágios posteriores.

A relação entre a música e a palavra é bem mais complicada teoricamente. Justamente essa complicação indica sua solução de princípio. Como problematizado, a "linguagem" poética produz sua própria "lógica". Isto é, essa "linguagem" tem o caráter de superar - com conservação - a rigidez lógica presente no silogismo da abstração conceitual da palavra.

A antropomorfização que a "linguagem" poética produz cria certo equilíbrio entre o sentido lógico do objeto que a palavra expressa e seu caráter sensível; aqui, frequentemente, há a existência do predomínio do elemento sensível sobre o lógico. As palavras e as frases, submetidas à "linguagem" poética, distanciam-se do conceito puramente lógico e assumem a tendência de se aproximar da flexibilidade da imaginação. Essa movimentação dialética alcança uma específica atmosfera que é, ao mesmo tempo, típica e única. Como sintetiza a formulação de Lukács: uma aura emocional desencadeada pelas palavras e que, por sua vez, as desencadeia.

Sobre esse debate, vale advertir, com o autor, que um bom texto poético não garante a produção de uma grande composição musical. Para Lukács, a entrega extrema e com fidelidade completa a um texto de decidida qualidade poética pode possibilitar que a conformação musical vá além da aura proporcionada pelos sons verbais, ou seja, que consiga superar a atmosfera psíquica da linguagem falada.

De outro modo, como a música é uma refiguração de uma refiguração, existem muitos exemplos em que a música opera o milagre mundano de prestar a formidável glória da emoção a poemas de medíocre qualidade. Como sintetiza Lukács (ibíd.: 4/65): “A grande palavra do poeta é, como todo o externo, mero pretexto; pretexto, certamente, que presta à dupla mimese uma intensificada concreção interna, porém também podia servir perfeitamente como base verbal a uma música medíocre".

A contradição existente entre a "lógica" da palavra artística e a musical tem como base que esta se funda no desdobramento vital dos sentimentos e o faz sem ressalvas; já a poesia existente na palavra apanha os sentimentos como se fossem elementos entre outros tais e precisa estar sempre subordinada ao movimento dialético da totalidade.

Esse debate chama a emergência da polêmica em torno da questão do realismo musical, dado que para muitos estetas não há sentido falar de realismo e suas negações na música. Para confundir ainda mais o tema, aplica-se à música o 
conceito de "realismo", distanciando-o do que é realmente particular ao campo musical. A natureza desta arte não pode ser confundida com semelhança ou com o seu contrário. É preciso distanciar-se da chamada ideia básica que conceitua genericamente a verdade ou falsidade a partir dessa ideia, assumindo-a como critério de "realismo" musical. Esse caminho apenas pode deformar a objetividade radicalmente indeterminada presente na música.

Perante as falsas teorias que inundam a questão, é preciso buscar um tertium datur (lei do terceiro excluído). Para avançar sobre esse conjunto problemático, Lukács levanta as seguintes perguntas de fundo: a existência elementar dos elementos sonoros da música, que vão da entonação e melodia ao mais complicado problema de harmonização, aponta para a superficialidade ou para a profundidade? Amplia a largura da vivência ou a estreita, invalidando os sentimentos que entram na mimese da música como reflexos de reflexões dos eventos do mundo externo e do mundo interno?

Quando se considera a obra em sua totalidade, a análise correta indica que uma obra musical se compõe de uma ininterrupta e recíproca mutação de conteúdo e forma. Claro está que, por refigurar fortemente o interior humano, o resultado musical apenas pode se inclinar para a profundidade e para a ampliação vivencial do sujeito que se reflete no caso dado. Em outras palavras, a objetividade radicalmente indeterminada consuma-se por meio de sua inseparável imbricação com a objetividade determinada internamente. Isto é: quanto mais o requisito de entendimento da música tiver como base a relação objetiva determinada e indeterminada, tanto mais a análise aproxima-se de uma profícua relação entre os critérios do realismo na música e os que têm validade para as outras artes.

O preciso sentido em que se pode falar de realismo em música justifica-se, como explica Lukács (ibíd.: 4/75), pelo fato de que:

[...] tampouco as artes que reproduzem com imediatez artística a objetividade imediata do mundo externo se orientam - precisamente a partir do ponto de vista do realismo estético - a uma simples reprodução, nem menos a uma reprodução fotográfica, senão a dar significação sensível à coincidência da aparência e a essência no fenômeno que, assim se faz, ao mesmo tempo, próximo à vida e distante desta, na nova imediatez do meio homogêneo de cada caso. $\mathrm{O}$ acesso formal à música é uma realização específica desse princípio. Ainda mais claramente se aprecia essa conexão na estrutura, na natureza do conteúdo evocador, pela concreta totalidade de cada obra. $O$ realismo de seu caráter se decide a favor da profundidade e precisão, a amplitude e a autenticidade com que é capaz de reproduzir e suscitar os problemas do instante pessoal e histórico de sua gênese segundo a perspectiva de sua significação duradora na evolução da humanidade.

A catarse também serve de mote para se diferenciar a música das demais artes, pois aqui coexiste a interação do mundo externo com o interno do humano. Os conflitos e as catástrofes da humanidade, quando objetivamente refigurados, 
desencadeiam uma comoção libertadora que possibilita certo desdobramento subjetivo vivencial das emoções. Essa vivência libertadora, ao entrar em contraste com a interioridade própria da vida concreta, realiza-se de modo demasiadamente intensificado.

A comoção libertadora que opera no campo musical, por sua natureza de dupla refiguração, age com tanta energia e profundidade que arrasta o indivíduo sob seu efeito por um mundo novo, entregando-o ao poder absoluto de um efeito catártico possível apenas à mimese da mimese presente na música. A força dessa intensidade, como abordado, acaba por dificultar, mais que nas outras artes, a eficácia construtiva do Depois sobre o sujeito receptivo.

Nas demais refigurações artísticas ocorre certa intensificação de experiências débeis e dispersas que estão presentes na vida cotidiana, bem como uma maior aproximação da orientação do Depois em sentido ético. No caso musical, a "aplicação" à vida, "[...] a transformação da catarse estética em suas consequências éticas, nas do comportamento, é muito mais difícil” (ibíd.: 4/77).

A música moderna possui a capacidade de operar essa peculiar comoção catártica. Motivada por sua incomensurável ampliação intensivo-extensiva do âmbito das emoções, a música moderna consegue converter as emoções em instrumento tanto da vida individual quanto da privada. Esse processo, com essa dimensão de intensa comoção, apenas pode ser alcançado artisticamente sobre a base da evolução geral da sociedade; por isso, seu quilate comotivo era antes inimaginável.

Esse processo catártico musical ocorre de modo duplo e contraditório. Se, por um lado, pode liberar todas as emoções, por outro, cria a possibilidade para que se produza a liberação da mera particularidade autoconsciente.

No primeiro caso, a catarse tende a levar o indivíduo acometido às últimas consequências da problemática causadora da comoção, que, por seu movimento, está cada vez mais tragicamente aprofundada, visto que existe sob a inibição e deformação do capitalismo. Mesmo perante as amarras capitalistas, essa classe catártica pode tornar perceptível a profunda - ainda que oculta - vinculação entre as emoções isoladas no mundo burguês e a evolução da vida concreta, suas lutas, esperanças, decepções, desesperos (os dramas humanos); pode ainda dar visibilidade às mais autênticas e elevadas perspectivas do gênero humano. Esse patamar é conquistado, precisamente, pela homogeneizadora depuração posta em ação pelo meio musical.

No segundo caso, enfrentando as mesmas inibições próprias do modo de produção capitalista, segue-se a possibilidade completamente contraposta à anteriormente tratada. Em consequência do isolamento individual, causado pela objetividade radicalmente indeterminada em relação à interioridade humana, o sujeito humano encontra-se afundado em sua esfera privada, o que 
possibilita a liberação da invasão súbita de uma classe de particularidades ligadas diretamente à personalidade privada. ${ }^{7}$

As especificidades musicais, com a concentração do meio homogêneo em uma intensidade para-si, pode explicitar também uma liberação em que se produz 0 contrário da catarse. Como esclarece Lukács (1967: 4/79 y s.), na esfera da música ocorre o que dificilmente haverá nas demais artes, ou seja, uma reconciliação da individualidade particular consigo mesma, que se processa pelos seguintes passos: "[...] por meio da sublimação musical formal - e somente formal - do emotivo, por intermédio de uma eliminação de todo mundo externo perturbador, por meio de uma sugestiva fixação e nivelamento das emoções ao nível de uma baixa particularidade e de termo médio".

\section{Algumas considerações}

Para concluir o tratamento que Lukács dá ao campo musical, sem naturalmente esgotá-lo, resta tematizar, de um modo mais específico, a questão da particularidade na música. $O$ que mais interessa destacar, segundo o autor, é a conexão entre o caráter criador do mundo da arte e a superação da particularidade do sujeito vivente, o que se observa, com clareza, desde o surgimento da música romântica até os dias atuais.

No que se refere especificamente ao campo da música, mas que dialoga com as demais artes, toma-se como princípio que toda arte musical substantiva cria um mundo próprio. Esse princípio é o fundamento estético mais profundo, cuja claridade recusa todo ponto de vista formalista, bem como as teorias que entendem a vivência musical como uma fusão quase mística entre o ouvido e o ouvinte. O que é próprio da música, seu efeito imanente, consiste no fato de que o meio musical introduz o receptor em seu mundo, que agora é esteticamente conformado para a música.

Graças a uma determinada diversidade específica, o meio musical faz com que o vivente usufrua intensa e extensamente esse mundo conformado. Embora exista uma penetração muito profunda e embora haja a mais enérgica liberação das emoções, graças a essa mesma diversidade tal mundo se ergue sempre como diverso do Eu do receptor, como um mundo distinto dele, mas que lhe é profundamente significativo. $\mathrm{O}$ mundo conformado esteticamente na música recebe seus conteúdos da totalidade social e das emoções que nela se revelam, para assim formar seu mundo para-si.

Esse mundo, no entanto, apenas está garantido quando tais emoções são humanamente essenciais, somente quando elas são capazes de desdobrar, até as últimas consequências, as emoções que elas mesmas desencadeiam. Apenas desse 
modo pode se erguer o mundo em sentido artístico: o mundo musicalmente conformado. Dessa dialética não se exclui a subjetividade do criador artístico; ao contrário, a ousadia, a originalidade, a capacidade de dar forma a um conteúdo vital, entre outros elementos relativos à conformação da obra, nascem da luta, nada pacífica, do artista para expressar adequadamente essa ampla ordenação.

Necessário advertir que os modelos musicais que ficam amarrados na particularidade do sujeito humano, limitado ao cotidiano, não têm como produzir um mundo esteticamente conformado ao meio homogêneo da música. Esses modelos - atualmente, talvez sejam os predominantes - restringem-se a levar para o sujeito vivente a interna insuficiência, a interna fragmentariedade, propondo ao receptor apenas uma conciliação aparente e formal. A mimese dessa mimese, com efeito, está impedida de criar um mundo próprio ao humano do sujeito vivente; ela apenas pode se confundir formalmente com a forma artística, jamais atingir a autenticidade exigida pela comoção catártica.

A tematização sobre quais são as emoções responsáveis por produzir e suportar um mundo próprio ao humano, portanto, autenticamente musical, é um problema que cabe às contradições histórico-sociais do desenvolvimento desigual da sociedade. Por exemplo, as canções e danças populares tradicionais, ao contrário dos modelos vistos no parágrafo anterior, mesmo expressando intensiva e extensivamente um mundo emocional com decisivas limitações, podem fazer florescer a forma musical autêntica. Aqui, a totalidade da realidade refigurada, apesar dos limites estreitos impostos pela evolução social - sempre desigual - a determinadas comunidades, luta por superar problemas essenciais da vida humana.

Por captar as tradições mais conservadas e, ao mesmo tempo, as novidades mais ousadas de sua gente, essas manifestações conseguem conformar o mundo apropriado esteticamente pelo meio musical. Por não abrir mão de dar forma ao conteúdo vital genuinamente ligado aos problemas humanos, essa música, por meio da catarse, patenteia a autêntica particularidade e despreza, sem remorso, a epidérmica, vulgar e grosseira particularidade que se esconde no juízo de gosto do sujeito preso ao cotidiano.

Parece óbvio, mas vale insistir, que a patente de autenticidade é um problema peculiar a todo o campo estético, não sendo possível uma linha divisória rigidamente precisa entre o que é autêntico e o que não é em arte. Também resta evidente que, para a Estética de Lukács (1967: 4/82), há uma prioridade do conteúdo vital humano sobre a forma: “[...] essa prioridade do conteúdo humano, essa determinação da forma como expressão do conteúdo concreto de cada caso e de sua particularidade, não é exclusiva da música, senão que esta [a música] a compartilha com todas as demais artes".

Após relembrar esses dois pontos, estamos aptos para concluir as reflexões sobre a música presente na Grande Estética de Lukács, apontando que a natureza matematizável da música indica que nela, mais que nas demais artes, é possível organizar critérios técnico-artísticos para enfrentar o problema do autêntico e do inautêntico. 
A peculiaridade musical mais profunda, apesar da exatidão matemática, manifesta-se no fato de que sua mimese apanha a substância mais íntima e sutil do humano em uma relação de captação do objeto para-si. Explicando de outro modo: como a prioridade é do conteúdo sobre a forma, a conformação musical, por refigurar a interioridade da substância humana sob uma objetividade radicalmente indeterminada, é dotada de uma especial sensibilidade acerca do que é ou não é autenticamente humano. Isso faz com que a música reaja hipersensivelmente ao problema da autenticidade. Numa expressão: a música chega primeiro! 


\section{Q Bibliografia}

" Bíblia On-line (2019). Jeremias. Tradução de João Ferreira Almeida. Rio de Janeiro: Sociedade Bíblica do Brasil (SBB). Velho Testamento. Disponível em www.sbb.org. br (acesso efetuado em 8/1/2019).

" Chasin, I. (2008). "Música e mímesis: uma aproximação categorial e histórica ao pensamento musical". Em Revista Verinotio 9.

"Kant, I. (2001). Crítica da razão pura. Lisboa: Fundação Calouste Gulbenkian.

" Lukács, G. (1966). Estética 1: La peculiaridad de lo estético. Trad. de Manuel Sacristán. 4 vols. Barcelona: Grijalbo.

" Marx, K. (2018). Contribuição à crítica da economia política. São Paulo: Expressão Popular, 2008.

"Santos, D. (2018). Estética em Lukács: a criação de um mundo para chamar de seu. São Paulo: Instituto Lukács.

"Santos Neto, A. B. (2011). "Catarse (katharsis) como articulação entre estética e ética em G. Lukács". Trilhas Filosóficas vol. 4, n² 2.

"Science, C. (1993). "A praieira. En Chico Science / Nação Zumbi. Da lama ao caos. Sony Music, 1993. CD, Faixa 5. 